$$
\begin{aligned}
& \text { قسم طب الحيو'ن }
\end{aligned}
$$

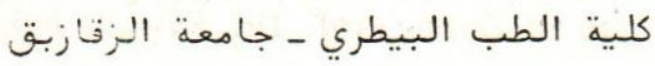

$$
\begin{aligned}
& \text { رئيس القسم : أ •د/ فوزية فهري }
\end{aligned}
$$

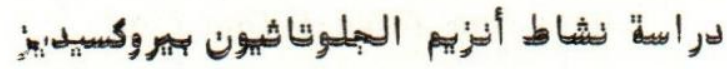 \\ وهلاقت بعنصر البلهبوم في دم البمال
}

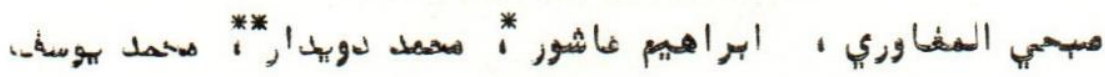

تمت الدراسة على عدد عشرون جمل لدراسة العلاقة بين أنزيم الجلوتاثيون بيروكسيديز وعنصر السلينوم في دم الجمال • وبعد التحليل الكيميائي الحيوي وتحليل النتائج احصائبيـا تببن أن هناك علاقة متوازية بين أنزيم الجلبوتاثيون ببروكسيديز وعنصر السنبنـمز ونظرا لكون العنصر جزءا أساسيا في مكونات الأنزيم • لذا يعتبر قياس هستوي نشاط الأنزيم في كريات الدم الحمراء مؤشر لمستوى العنصر في الجمل| -

* قسم الكيمياء الحيوية - كلية الطب البيطري - جامعة قناة السويس *** قسم الكيمياء الحيوية - كلية الطب البية البطري ـ - جامعة الزقازيق 
Dept. of Medicine and Infectious Disease,

Faculty of Vet. Med., Zagazig Univ.,

Head of Dept. Prof. Dr. Fawzia Fahmy.

\title{
GLUTATHIONE PEROXIDASE ACTIVITY IN CAMELS ERYTHROCYTES (CAMELUS DROMEDARIUS) IN RELATION TO BLOOD SELENIUM CONCENTRATION (With One Table \& One Fig.)
}

\author{
By \\ S.M. EL-MAGAWRY; I.A. IBRAHIM*; M.F. DOWIDAR ** \\ and M.A. YOUSIF \\ (Received at 15/12/1987)
}

\begin{abstract}
SUMMARY
Glutathione peroxidase activity (GSH-PX) and selenium concentration (Se) were determined in the blood of camels (Camelus Dromedarius) under field conditions. There was a highly significant correlation ( $r=0.935, P / 0.001)$ between glutathione peroxidase activity (GSHPX) in R.B.Cs and whole blood selenium concentration.

Our results suggest that GSH-Px activity in erythrocytes could be used as a basis for rapid monitoring method for assessing the selenium status in camels, and that is the preliminary data on normal levels in camels.
\end{abstract}

\section{INTRODUCTION}

Determination of an animal's selenium requirement and status was until recently depending on time consuming methods and highly specialized laboratory equipment. The discovery that selenium is an integral part of the enzyme glutathione peroxidase (GSH-PX) and that selenium through this erizyme exerts protection against peroxidative damage like vit E (ROTRUCK, et al. 1973 \& TAPPEL, 1974) has, however, contributed considerably not only to a better understandir.g of the synergistic effect of two nutritive elements, but also to the development of sensitive index of the selenium status. It sppears that, the blood selenium and GSH-Px content is coseir correlated in various species including cattle and sheep (ALLEN, et al. 1975 and IHOMPSON, et al. 1976). Thus, analysis of this enzyme in blood may therefore provides a valuabie ir,dex to monitor abnormal levels of enzyme activity related to improper selenium supplementatior.

ir. camels, there is no available literature have been published previously concerning seleriium status and GSH-Px activity.

Inerefore, the present work was planned to give a preliminary study on the relationship betweer. selenium ( $\mathrm{Se}$ ) and glutathione peroxidase activity (GSH-PX) of camels under field conditions. Another object was to investigate the usefulness of blood GSH-Px assay in determiriing Se-status of camels.

* Dept. of Biochemistry \& Physiology, Fac. of Vet. Med., Suez Canal Univ.

** Dept. of Biochemistry \& Physiology, Fac. of Vet. Med., Zagazig Univ. 


\section{S.M. EL-MAGAWRY, et al.}

\section{MATERIAL and METHODS}

Twenty camels (Camelus Dromedarius, L.) 3 to 5 years old, and weighted from 350-500 k.g. B.Wt., were used in this study. These camels included 15 males and 5 females (non-pregriant).

These animals were clinically healthy, proved from general clinical examination, in addition to their blood and faecal samples that were free from blood and/or internal parasites.

Blood samples were obtained from jugular vein into a $20-\mathrm{ml}$ heparinized evacuated tube ${ }^{a}$, while camels kept were in a recumbent position.

Glutathione peroxidase (GSH-Px: glutathione $\mathrm{H}_{2} \mathrm{O}_{2}$ oxidoreductase $1.11 .1 \mathrm{~g}$ ) activity was determined in 3 times washed red blood cells, according to the modification by ALLEN, et al. (1975) of the method of PAGLIA and VALENTINE (1967). Enzyme activity was expressed as units, where one unit was equivalent to $1 \mathrm{Umol} \mathrm{NADPH}$ oxidized $/ \mathrm{min} . / \mathrm{gm} \mathrm{Hb}$ at $25^{\circ} \mathrm{C}$. While whole blood selenium concentration (se) was determined by the technique of $\mathrm{KOH}$ and BENSON (1983).

Standard statistical methods were used for calculating the correlation coefficient between glutathione peroxidase activity (GSH-Px) and whole blood selenium concentration (Se) after SNEDECOR and COCHRAN (1973).

\section{RESULTS}

The results of blood seleinium (Se) concentration and glutathione peroxidase activity (GSH-PX) of 20 healthy camels of both sexes were summarized in Table (1). The blood selenium levels were ranging from 0.048 to 0.102 with a mean vlaue of $0.065+0.008 \mathrm{Ug} / \mathrm{ml}$ and 0.046 to 0.090 with a mean vlaue of $0.065+0.009 \mathrm{Ug} / \mathrm{ml}$ for both male and female camels, respectively. Their Their corresponding glutathione peroxidase activity (GSH-PX) were ranging from 16.923 to 35.727 with a mean value of $25.002+0.641 \mathrm{lu} / \mathrm{gm} \mathrm{Hb}$ and from 16.007 to 32.842 with a mean vlaue of $23.73+0.172 \mathrm{lu} / \mathrm{gm} \mathrm{Hb}$ for both male, and female camels, respectively.

The relationship between glutathione peroxidase activity ( $y$ ) and selenium concentration ( $x$ ) in blood was determined by analysis of samples collected from camels (Fig. 1). The enzyme activity was positively correlated to the selenium concentration $(P / 0.001, r=0.935)$. The regression equation was $y=-0.167+357.252 \times$.

There was no significant difference in both values of selenium and glutathione peroxidase activity (GSH-PX) between male and female examined camels blood.

\section{DISCUSSION}

The identification of more and more vitamin and trace element enzyme associations forms the basic of a new methodology by which deficiencies may be detected with a sensitivity not obtainable by current methods. The recent discovery that glutathione peroxidase activity (GSH-PX) is a seleno-enzyme has widened considerably the possibilities not only for the elucidation of the biochemical role of this trace element, but also for the detection of selenium deficiency status.

a Vacutainer, Becton-Dickinson and Co., Rutherford, N.J. 07070. 


\section{BLOOD SELENIUM IN CAMELS}

The results of this study showed a strong and positive correlation between selenium (Se) concentration and glutathione peroxidase activity $(G S H-P x)$ in erythrocytes of camels $(P / 0.001$, $\tau=0.935)$ Fig. 1, with a mean value of $0.066+0.008$ and $0.065+0.009 \mathrm{Ug} / \mathrm{ml}$ for selenium concentrationin both male and female camels, respectively. While their corresponding glutathione peroxidase activity (GSH-Px) were $25.002 \pm 0.041$ and $23.73 \pm 0.172 \mathrm{l} . \mathrm{U} / \mathrm{gm} \mathrm{Hb}$, for both male and female camels. respectively (Table 1).

Similar correlation had been established in cattle, sheep and pigs (ALLEN, et al. 1975; THOMPSON, et al. 1976 and JORGENSEN, et al. 1977).

Therefore, it can be concluded that, glutathione peroxidase activity (GSH-PX) determineded by simple erizymatic analysis. appears to be a satisfactory indicator and a rapid mointoring method for assessing the selenium status in camels.

\section{REFERENCES}

Allen, W.M.; Parr, W.H. and Anderson, P.H. (1975): Selenium and the activity of glutathione peroxidase in bovine erythrocytes. Veterinary Record. 96, 360-361.

Jorgensen, P.F.; Jensen, J.H. and Moustgaard (1977): Glutathione proxidase activity in procine blood. Acta. Vet. Scand., 18, 323-334.

Koh, T.S. and Benson, T.H. (1983): Critical re-appraisal of fluorometric methods for determination of selenium in blood in biological materials. J. Assoc. off. Anal. Chem. 66 (4): 918-926.

Paglia, D.E. ar.d Valentine, W.N. (1967): Studies on the quantitative and qualitative characterization of erythrocyte glutathione peroxidase. J. Lab. Clin. Med. 70: 158-169.

Rotruck, J.T.: Pope, A.L.; Garither, H.E.: Swarison, A.B.; Hafeman, D.G. and Hoekstra, W.G. (1973): Selemium: Biochemical role as a component of glutathione peroxidase. Science. 179. 588-590.

Snedecor. G.W. ar.d Cochran, W.G. (1973): Statistical Methods. 6th Ed. lowa State Univ. Press, Ames.

Tappel. A.L. (1974): Selenium-glutathione peroxidase and Vit. E. Am. J. Clin. Nutr. 27: 960-965.

Thompsor, P.H.: MoMurtay, C.H. and Blanchilower, W.J. (1976): The levels of selenium and glutathione peroxidase activity in blond of sheep, cows and pigs Research in Vet. scierice. 20. $229-231$.

Table (1)

Results of blood selenium (Se) and glutathione peroxidase activity (GSH-PX) in camels under field conditin

\begin{tabular}{|c|c|c|c|c|c|}
\hline \multirow{2}{*}{ Sex } & \multirow{2}{*}{ No. } & \multicolumn{2}{|c|}{ GSH-Px (lu/gm Hb) } & \multicolumn{2}{|c|}{ Selenium $(\mathrm{Ug} / \mathrm{ml})$} \\
\hline & & Mean \pm S.E. & Range & Mean \pm S.E. & Range \\
\hline Male & 15 & $25.002+0.841$ & $16.923-35.727$ & $0.066 \pm 0.008$ & $0.040-0.102$ \\
\hline Female & 5 & $23.73 \pm 0.172$ & $16.077-32.154$ & $0.65 \pm 0.009$ & $0.046-0.090$ \\
\hline
\end{tabular}




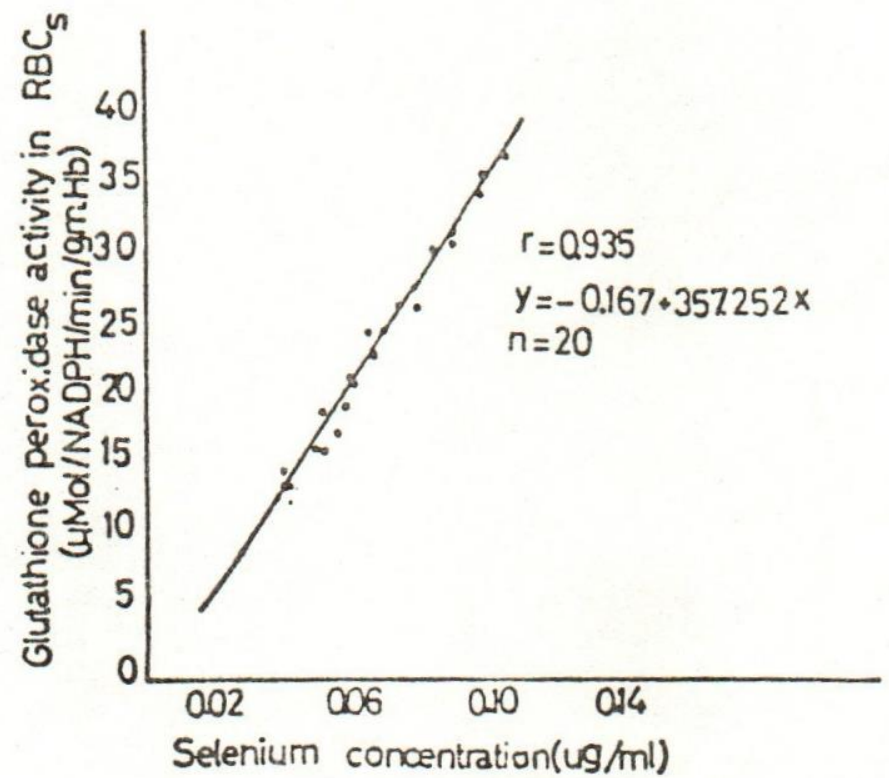

Fig. (1)

Correlation between whole blood selenium (Se) concentration and glutathinone peroxidase activity in R.B.Cs of camels 
